\title{
The global post-2015 sustainable development debate What can regions offer?
}

Volume five of Regions \& Cohesion has focused significant attention on the subject of regional development. It has done so because 2015 is such an important year in relation to development debates given the definition of the post-Millennium Development Goals (MDGs) agenda in the United Nations and the official declaration of 2015 as the European Union Year for Development. The introduction to the Leadership Forum of the Spring 2015 issue included important reflections on the theme of "transformative development." The introduction openly asked whether 2015 could be a decisive year for the global development agenda or whether it will be remembered for global summitry, international declarations and little more.

This special issue continues the journal's reflections on these themes. The editors are grateful to Dr. Cristina Blanco Sío-López for assembling this special issue on "Policy innovation, regional integration and sustainable democracy building: The Millennium Development Goals (MDGs) as challenges and vehicles." This special issue presents articles that discuss the added value of regions to sustainable development strategies. It discusses development processes and governance both within and between regions. In doing so, it examines how both regionalism and interregionalism affect sustainable development in broader political contexts.

This reflection is important because the debate on post-MDG development goals has been largely inclusive-through discussions with government officials, representatives of civil society and multinational corporations, and individual citizens-but it has diminished the role of regional organizations outside of the European Union in these discussions. This structural constraint seems counterproductive to sustainable development strategies given that regional and interregional cooperation lie at the heart of trade agreements, environmental conservation conventions, security regimes, development assistance and other policy arenas that are central elements of sustainable development strategies. How can we expect to achieve policy coherence for development when regions are not centrally placed in broader development discussions? In response to 
this question, as well as those posed by Dr. Blanco Sío-López in her introduction article, Regions $\mathcal{E}$ Cohesion is pleased to publish this special issue which places regionalism and interregionalism at the heart of sustainable development debates through the lens of regional policy innovation. This approach (policy innovation) should be emphasized as a significant component of transformative development. Its presence/absence in post-MDG development strategies will certainly affect the impacts of the development decisions taken in 2015.

We should also mention that 2015 is a year of hope for many participating in global development discussions. Honoring the spirit of this moment, the Consortium for Comparative Research on Regional Integration and Social Cohesion (RISC) launched a photo/essay contest entitled "World Family Portrait." The goal of this ongoing call for contributions is to engage readers through photography and prose in a dialogue focusing on the evolution of our world and humanity's place in it. The project is inspired by Edward Steichen's photographic exhibition "The Family of Man", which opened at New York's Museum of Modern Art in 1955. "The Family of Man" shows mankind in different physical, psychological and emotional states from birth to death. It transcends cultural boundaries and unites humanity through our common characteristics. The exhibition documents the evolution of society and initiates a dialogue with viewers on social issues. In recognition of Dr. Cristina Blanco Sío-López's commitment to social justice and interregional dialogues and with thanks for her hard work as guest editor of this special issue, we publish three of her photos submitted to the "World Family Portrait" call for contributions. The other selected photos/essays will be published in Regions \& Cohesion's "Leadership Forum" in 2016. More information on "World Family Portrait" can be found at www.risc.lu.

The Editors 